\title{
Hematology and agglutination titer after polyvalent immunization and subsequent challenge with Aeromonas hydrophila in Nile tilapia (Oreochromis niloticus)
}

\author{
Hematología y título de aglutinación después de inmunización polivalente y \\ desafío con Aeromonas hydrophila a tilapias del Nilo (Oreochromis niloticus)

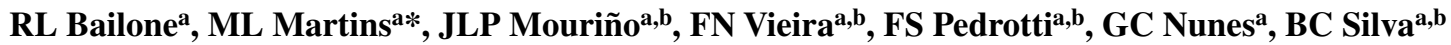 \\ aLaboratório AQUOS - Sanidade de Organismos Aquáticos, Departamento de Aqüicultura \\ Centro de Ciências Agrarias (CCA), Universidade Federal de Santa Catarina, Florianópolis, SC, Brasil. \\ bSetor de Microbiologia, Laboratório de Camarões Marinhos, Departamento de Aqüicultura, CCA, Universidade Federal \\ de Santa Caterina, Florianópolis, SC, Brasil.
}

\begin{abstract}
RESUMEN
Este trabajo evaluó el efecto de la vacuna polivalente sobre las respuestas hematológicas y inmunológicas de tilapias del Nilo desafiadas con Aeromonas hydrophila. Dos dosis, 1 × $10^{4}$ y 1 × $10^{8}$ Unidades Formadoras de Colonias (UFC)/mL, de vacuna conteniendo proporciones iguales de Aeromonas hydrophila, Pseudomonas aeruginosa y Enterococcus durans inactivadas con formalina, fueron testeadas por inyección intraperitoneal (i.p.). Los peces fueron desafiados 10 días después de la vacunación i.p. con la dosis $\left(\mathrm{DL}_{50-96 \mathrm{~h}}\right)$ de 1 x $10^{7} \mathrm{UFC}$ de $A$. hydrophila/mL resuspendida en solución salina estéril. Por lo tanto, para analizar los parámetros hematológicos, la actividad antimicrobiana y aglutinante del suero de las muestras, fueron colectadas $48 \mathrm{~h}$ después del desafío. Antes de la infección experimental, el número de eritrocitos fue superior en los peces vacunados con 1 x $10^{8}$ $\mathrm{UFC} / \mathrm{mL}$. Sin embargo, después del desafío, el número total de trombocitos fue mayor en los peces vacunados con la mayor dosis. Antes y después del desafío, el número total de leucocitos y el número de linfocitos presentaron mayores valores en los peces vacunados. El número de monocitos en los peces vacunados y en los inyectados con solución salina fue mayor antes del desafío. El mayor título de aglutinación frente A. hydrophila, P. aeruginosa y $E$. durans fue observado en los peces vacunados con 1 x $10^{8} \mathrm{UFC} / \mathrm{mL}$. Antes del desafío la actividad antimicrobiana del suero sanguíneo fue mayor en los peces no vacunados y en los vacunados con 1 x $10^{8} \mathrm{UFC} / \mathrm{mL}$, y mismo después del desafío los peces no vacunados y los inyectados con solución salina presentaron mayor actividad antimicrobiana. En este trabajo fue posible comprobar que después de 10 días la vacuna polivalente en la concentración de $1 \times 10^{8} \mathrm{UFC} / \mathrm{mL}$ estimuló la producción de eritrocitos, leucocitos, trombocitos y linfocitos circulantes reduciendo los niveles de glucosa.
\end{abstract}

Key words: Oreochromis niloticus, vaccination, Aeromonas hydrophila, challenge.

Palabras clave: Oreochromis niloticus, vacunación, Aeromonas hydrophila, desafío.

\section{INTRODUCTION}

The rapid development of aquaculture allied to intensive production systems favour stress conditions in captive fish, leading to diseases and economic losses (Schreck 1996). One of the most important challenges in aquaculture is the enhancement of performance and disease resistance in reared fish. In this sense bacterial diseases are one of the limitant factors (Abdel-Tawwab et al 2008, Martins et al $\left.2009^{\mathrm{a}}\right)$. Bacteria are part of microrganisms present in the water of rivers and ponds, and its pathogenic potential may be altered under physical and chemical characteristics of the environment (Walters and Plumb 1980). Gram negative, worldwide and opportunist bacterium Aeromonas hydrophila, may cause disease in a several freshwater

\footnotetext{
Accepted: 14.07.2010.

* Rod Admar Gonzaga, 1346, 88040-900; Florianópolis, SC, Brasil; mlaterca@cca.ufsc.br
}

fish species for example in cyprinid as related by Rahman et al (1997).

Antibiotics are frequently utilized in aquaculture to increase larval resistance but this practice can also result in microbial resistance, residual accumulation in tissue (Vadstein 1997) and fish immunesuppression (Van Muiswinkel et al 1985). The immuneprophylaxis as the specific and non-specific immune system stimulation is the key for sustainable aquaculture development (Gudding et al 1999). Vaccination with inactivated antigens as well as the probiotic addition in the diet of cultured fish may contribute to reduction of chemicals and antibiotics in aquaculture (Gudmundsdóttir and Björnsdóttir 2007, Jatobá et al 2008).

In Brazil, studies on fish immunology are scarce. The administration of vaccines against bacterial and viral diseases has demonstrated good results in relation to scientific and economic approaches by reducing the chemical use (Costa 2004). Several factors can interfere on fish immune response such as developmental stage, size, nutritional status, water 
quality and vitamin supplementation (Tatner and Manning, 1983, Bly et al 1997, Nakanishi and Ototake 1997, Moraes and Martins 2004, Martins et al 2008 a). On the other hand, the efficacy of the vaccine is strongly influenced by the type of administration, dose and nature of antigens, adjuvant addition, environment and water temperature (Tatner 1987, Lillehaug et al 1993, Bly et al 1997). Thus, information on the infectious agent and the host response must be considered for the development of an efficient vaccine (Gudmundsdóttir and Björnsdóttir 2007).

The resistance of fish can be evaluated by analyzing the survival rate after experimental infection (Wasson and Kelly 1990) as well as hematological and immunological parameters (Martins et al 2009a). A combined vaccine against Streptococcus iniae administrated intraperitoneally in tilapia has demonstrated more protection compared to a single isolate (Klesius et al 2000). The authors argued that antigen heterogenicity in Streptococcus exists and a combined vaccine may enhance fish response.

Park and Jeong (1996) reported improved resistance in tilapia injected with protein-bound polysaccharide (PS-K) against Edwardsiella tarda. Sarder et al (2001), found that lysozyme and phagocytic activities in tilapia were higher after challenge with A. hydrophila, but no difference was noted in the differential counting of leukocytes. On the other hand, Castro et al (2008) observed good results in turbot Scophthalmus maximus vaccinated against $E$. tarda characterized by the highest survival rate and antibody levels for at least six months after immunization.

According to Balfry et al (1997) lymphocyte number decreased after challenge with Vibrio parahaemolyticus but no difference in thrombocyte, neutrophill and monocyte was found. The study of Harikrishnan et al (2003) in carp infected by $A$. hydrophila showed an increase in the leukocyte number. But the opposite was foud in pacu Piaractus mesopotamicus experimentally infected with A. hydrophila (Garcia et al 2007). Martins et al $\left(2008^{\mathrm{b}}\right)$ have reported that Enterococcus-injected tilapia showed not only a high number of thrombocytes, but also an increase in white blood cell and lymphocyte when compared to noninjected. Phagocytyc activity and circulating lymphocyte number were also enhanced after Enterococcus injection (Martins et al 2009a).

This study evaluated the effects of polyvalent vaccination containing A. hydrophila, Pseudomonas aeruginosa and E. durans, on the hematological and serum agglutination responses in Nile tilapia challenged with A. hydrophila.

\section{MATERIAL AND METHODS}

The experiment was carried out at the Aquaculture Department, Laboratory AQUOS-Aquatic Organisms Health, CCA, UFSC, Florianopolis, Santa Catarina State, with GIFT tilapia from "Fundação 25 de Julho", Joinville, SC, Southern Brazil.
The strains of A. hydrophila ATCC 7966, Enterococcus durans ATCC 19492, Pseudomonas aeruginosa ATCC 27853 and Escherichia coli ATCC 25922 used in this assay were donated by Institute André Tossello (Campinas, São Paulo State), and cultured at the Microbiology Laboratory of Marine Shrimp Laboratory, UFSC, Florianópolis, SC.

\section{LETHAL DOSE $\left(\mathrm{LD}_{50-96 \mathrm{H}}\right)$ TO AEROMONAS HYDROPHILA}

Fish with $196.97 \pm 25.00 \mathrm{~g}$ weight and $18.53 \pm 1.20$ $\mathrm{cm}$ length were distributed in $150 \mathrm{~L}$ tanks with constant aeration and water renewal $30 \%$ a day, and fed ad libitum with a commercial diet $28 \%$ crude protein twice a day. After acclimation for 5 days, fish were intraperitoneally (i.p.) injected with $0 ; 1 \times 10^{5} ; 1 \times 10^{6} ; 1 \times 10^{7}$ and $1 \times 10^{8}$ Forming Colony Units (FCU)/mL per fish diluted in $1 \mathrm{~mL}$ esterile saline solution, in triplicates with 5 fish in each repetition. The water quality was daily monitored as follows: dissolved oxygen $5.54 \pm 0.44 \mathrm{mgL}$; temperature $24.93 \pm 2.49{ }^{\circ} \mathrm{C} ; \mathrm{pH} 7.29 \pm 0.30$; total ammonia $0.45 \pm 0.48 \mathrm{mg} / \mathrm{L}$.

After $96 \mathrm{~h}$ of mortality observation, $\mathrm{DL}_{50-96 \mathrm{~h}}$ was estimated for A. hydrophila by the method Trimmed Spearman-Karber (Hamilton et al 1977). Bacterial concentration that provoked $50 \%$ mortality in $96 \mathrm{~h}$ was utilized to challenge the fish. Furthermore, as an experimental vaccination, a previously reported lower dose (Martins et al $2008^{\mathrm{b}}$ ) and a time collection that caused no severe mortality were used.

\section{VACCINATION AND CHALLENGE}

Bacterial strains of A. hydrophila, $P$. aeruginosa and E. durans were reproduced in separate tubes of $10 \mathrm{~mL}$ containing BHI broth (Brain and Heart Infusion, Difco), incubated at $30^{\circ} \mathrm{C}$ for $24 \mathrm{~h}$ under continuous agitation. After verifying the bacterial population, equal portions of bacteria were added to formalin $0.5 \%$, being incubated again under agitation at $30^{\circ} \mathrm{C}$ for $24 \mathrm{~h}$. Bacterial cultures were centrifuged at 4,000 $\mathrm{g}$ for $30 \mathrm{~min}$, the supernatant with formalin was discarded and the pellet re-suspended in sterile saline solution. The vaccine was determined to be sterile by lack of growth in TSA (Tryptic Soy Agar, Difco) medium culture at $30^{\circ} \mathrm{C}$ for $24 \mathrm{~h}$.

Fish with $255.52 \pm 21.16 \mathrm{~g}$ weight and $21.28 \pm 1.93$ $\mathrm{cm}$ length were distributed in $150 \mathrm{~L}$ tanks with constant aeration and water renewal $30 \%$ a day. Fish were acclimated for 10 days and fed ad libitum with a commercial $\operatorname{diet} 28 \%$ crude protein twice a day. Water quality was daily monitored as follows: dissolved oxygen $5.43 \pm 0.48 \mathrm{mg} / \mathrm{L}$; temperature $26.09 \pm 3.13{ }^{\circ} \mathrm{C} ; \mathrm{pH} 7.02 \pm 0.32$ and total ammonia $0.90 \pm 0.67 \mathrm{mg} / \mathrm{L}$.

The experiment was entirely randomized with i.p. vaccinated fish with $1 \times 10^{4}$ and $1 \times 10^{8} \mathrm{FCU} / \mathrm{mL}$ polyvalent vaccine formalin-inactivated; control saline-injected fish and non-injected ones, 10 fish per treatment, in triplicates. 
Before inoculation and for blood collection fish were anethestized with a benzocaine solution $(50 \mathrm{mg} / \mathrm{L})$ (Ethic Committee $\mathrm{n}^{\circ}$ 23080.024659/2007-99 CEUA/ UFSC). Fish were maintained in starvation for $24 \mathrm{~h}$ before challenge by i.p. $1 \mathrm{~mL}$ of $\mathrm{DL}_{50-96 \mathrm{~h}}$ A. hydrophila $\left(1 \times 10^{7} \mathrm{UFC} / \mathrm{mL}\right)$. This trial was carried out 10 days after immunization.

\section{HEMATOLOGY AND GLUCOSE}

Blood samples were collected before and $48 \mathrm{~h}$ after challenge with $A$. hydrophila. After fish anesthetizes, the blood was withdrawn from the caudal vein using a $3 \mathrm{~mL}$ (21G) syringe with 10\% EDTA and a syringe without anticoagulant. Blood collected without anticoagulant was left to clot for $2 \mathrm{~h}$ at $25^{\circ} \mathrm{C}$, and then centrifuged at $1,400 \mathrm{~g}$ for 10 minutes. Serum aliquot was taken with assist of a micropipette and stored at $-20^{\circ} \mathrm{C}$ until analysis. Serum of 3 fish from the same experimental aquarium was pooled for immunological analyses. The blood collected with anticoagulant was used to produce duplicates of blood ex tensions stained with Giemsa/MayGrunwald (Rosenfeld 1947), for differential counting of leukocytes and total counting of thrombocytes and leukocytes. One aliquot was used to determine hematocrit (Goldenfarb et al 1971) and the rest was stored in glass flasks on ice to quantify the total number of erythrocytes in a hemocytometer. Total number of thrombocytes and leukocytes were counted in blood extension by the indirect method described by Ishikawa et al (2008). One aliquot of serum was used to determine glycemic index in spectrophotometer (Biotécnica ${ }^{\circledR}$ kit) at $505 \mathrm{~nm}$.

In the first collection (ten days after immunization), three fish per each treatment were used for blood collection and euthanized. For the second collection ( $48 \mathrm{~h}$ after challenge) the other seven fish were utilized finally used.

\section{AGGLUTINATION TITER}

The test for agglutination titer was realized individually for each bacterium strain (A.hydrophila, E. durans and $P$. aeruoginosa) according to Yildirim et al (2003). The concentration of inactivated cells used in the test was of 0.8 in $550 \mathrm{~nm}$ wave length $\left(\mathrm{DO}_{550 \mathrm{~nm}}\right)$. Briefly, each well of a 96-round well microplate was plated with $50 \mu \mathrm{L}$ of phosphate-buffered saline (PBS 0.2M monobasic phosphate, $0.2 \mathrm{M}$ dibasic phosphate, $0.11 \mathrm{M}$ sodium chloride, $\mathrm{pH} 7.4$ ) and then $50 \mu \mathrm{L}$ of serum was added to the first well, and diluted serum was serially diluted into the remaining wells. After that, $50 \mu \mathrm{L}$ of each bacterium strain was added to each well and incubated in humidified air at $25{ }^{\circ} \mathrm{C}$ for $18 \mathrm{~h}$. The agglutination was measured as the amount of a required substance to react with a given amount of other substance, that was considered as reciprocal of the last dilution that presented agglutination.

\section{STATISTICAL ANALYSIS}

Data were analized using the Bartlett test and hematological parameters with no homogenicity in variance were transformed in $\log (x+1)$ prior to analysis of variance with parcels subdivided in time $(\alpha<0.05)$. Differences in means were detected by the Student Newman Keuls test (SNK), and agglutination titer data was $\log _{2}(x+1)$ transformed prior to analysis.

\section{RESULTS AND DISCUSSION}

\section{LETHAL DOSE}

The first mortalities occurred $11 \mathrm{~h}$ after challenge in all experimental units of the dose $1 \times 10^{8} \mathrm{UFC} / \mathrm{mL}$ (table 1). Except for saline-injected fish, all dead animals showed typical symptoms such as reddish on ventral body surface, scaleness, fin and integument hemorrhages with exposition of muscular tissue. After $23 \mathrm{~h}$ the first mortality was detected in fish that received the dose $1 \times 10^{7} \mathrm{UFC} / \mathrm{mL}$. Park and Jeong (1996) found mortality in tilapia $48 \mathrm{~h}$ after infection with $E$. tarda. Our results were similar to the findings of Sarder et al (2001) who observed tilapia mortality $12 \mathrm{~h}$ after infection with A. hydrophila. Balfry et al (1997) reported $28.9 \%$ mortality in black strain tilapia $24 \mathrm{~h}$ after challenge with $V$. parahaemolyticus. The mortality in saline-injected fish (6.66\%) has probably been caused by injection handling stress corroborating the findings of Sarder et al (2001). The stress due to saline injection was related in the studies of Martins et al (2006) in pacu (Piaractus mesopotamicus).

Except for the increased mortality rate in fish that received $1 \times 10^{5} \mathrm{CFU} / \mathrm{mL}$ in relation to those that received $1 \times 10^{6} \mathrm{CFU} / \mathrm{mL}$, the mortality was proportional to the concentration of pathogen inoculums. Fish inoculated with $1 \times 10^{7} \mathrm{CFU} / \mathrm{mL}$ showed 50\% mortality ( $\mathrm{DL}_{50-96 \mathrm{~h}} A$. hydrophila). Contrarily to here observed, Wang and Wang

Table 1. Mortality rate in Nile tilapia $96 \mathrm{~h}$ after intraperitoneal injection of saline solution and crescent dosis of Aeromonas hydrophila/mL, to determine the $\mathrm{DL}_{50-96 \mathrm{~h}}$.

Tasas de mortalidad en tilapia del Nilo después de 96 h de la inyección intraperitoneal inyección de solución salina y la creciente dosis de Aeromonas hydrophila/mL, para la determinación de la $\mathrm{DL}_{50-96 \mathrm{~h}}$.

\begin{tabular}{cc}
\hline $\begin{array}{c}\text { Colony forming units of } \\
\text { Aeromonas hydrophila/mL }\end{array}$ & $\begin{array}{c}\text { Mortality } \\
(\%)\end{array}$ \\
\hline Saline solution & 6.66 \\
$1 \times 10^{5}$ & 39.96 \\
$1 \times 10^{6}$ & 26.64 \\
$1 \times 10^{7}$ & 53.28 \\
$1 \times 10^{8}$ & 79.92 \\
\hline
\end{tabular}


(1997) found that injection with $1 \times 10^{7} \mathrm{CFU}$ A. hydrophilal $\mathrm{mL}$ in tilapia and carp caused $100 \%$ mortality $\left(\mathrm{DL}_{100}\right)$. It depends on several factors as environmental conditions and bacterial strain.

\section{HEMATOLOGY AND GLUCOSE}

As a result of stress, normal hematological parameters could be changed in infected fish (Martins et al 2008 ${ }^{\mathrm{b}}$ ). In this study, after challenge with A. hydrophila, the number of thrombocytes in the circulating blood of $1 \times 10^{8}$ vac- cinated tilapia was higher than the number observed in non-vaccinated ones (table 2).

The results showed an increase in the number of total leukocyte and lymphocyte in $1 \times 10^{8}$ vaccinated fish in relation to other treatments either after immunization or challenge (table 3 ). In the studies of Harikrishnan et al (2003) in carp (Cyprinus carpio) infected i.p. with A. hydrophila, the number of leukocyte increased until 30 days after infection. In contrast to that observed by Harikrishnan et al (2003), in this work erythrocyte number and hematocrit did not alter after challenge. On

Table 2. Blood characteristics in the blood of Nile tilapia, before ( 6 days after immunization) and $48 \mathrm{~h}$ after challenge with Aeromonas hydrophila. Non-vaccinated fish, fish injected with $1 \mathrm{~mL}$ saline solution, fish vaccinated with $1 \times 10^{4}$ and $1 \times 10^{8} \mathrm{CFU}$ of polyvalent vaccine $/ \mathrm{mL}$. Different letters indicate significant difference among the treatments in each time of collection by SNK test of mean comparison $(\mathrm{P}<0.05)$.

Características de la sangre de tilapia del Nilo, antes (6 días después de la inmunización) y 48 h después de infectarlas con Aeromonas hydrophila. Peces no infectados, e inyectados con $1 \mathrm{~mL}$ solución salina y peces vacunados con 1 x $10^{4}$ y 1 x $10^{8} \mathrm{CFU}$ con la vacuna polivalente/mL. Las letras distintas indican diferencia significativa entre los tratamientos en los distintos tiempos de colecta por el test de comparación de medias $\mathrm{SNK}(\mathrm{P}<0.05)$.

\begin{tabular}{|c|c|c|c|c|c|c|}
\hline Collection & Treatment & $\begin{array}{l}\text { Glucose } \\
(\mathrm{mg} / \mathrm{dL})\end{array}$ & $\begin{array}{c}\text { Hematocrit } \\
(\%)\end{array}$ & $\begin{array}{c}\text { Erythrocyte } \\
\left(10^{6} / \mu \mathrm{L}\right)\end{array}$ & $\begin{array}{l}\text { Thrombocyte } \\
\left(10^{3} / \mu \mathrm{L}\right)\end{array}$ & $\begin{array}{l}\text { Leukocyte } \\
\left(10^{3} / \mu \mathrm{L}\right)\end{array}$ \\
\hline \multirow{4}{*}{ Before challenge } & Non-vaccinated & $85.62 \pm 45.88^{\mathrm{a}}$ & $18.83 \pm 4.19^{\mathrm{a}}$ & $1.02 \pm 0.30^{\mathrm{b}}$ & $35.20 \pm 5.41^{\mathrm{a}}$ & $18.19 \pm 1.50^{\mathrm{b}}$ \\
\hline & Saline & $75.56 \pm 55.00^{\mathrm{a}}$ & $24.78 \pm 2.80^{\mathrm{a}}$ & $1.25 \pm 0.14^{\mathrm{ab}}$ & $46.66 \pm 12.68^{\mathrm{a}}$ & $21.80 \pm 5.65^{\mathrm{b}}$ \\
\hline & $1 \times 10^{4}$ & $21.91 \pm 21.77^{b}$ & $26.83 \pm 2.80^{a}$ & $1.34 \pm 0.28^{\mathrm{ab}}$ & $46.66 \pm 6.49^{a}$ & $26.35 \pm 5.20^{\mathrm{b}}$ \\
\hline & $1 \times 10^{8}$ & $42.81 \pm 18.69^{\mathrm{b}}$ & $23.33 \pm 4.93^{\mathrm{a}}$ & $1.70 \pm 0.22^{\mathrm{a}}$ & $49.41 \pm 10.41^{\mathrm{a}}$ & $34.72 \pm 10.09^{\mathrm{a}}$ \\
\hline \multirow{4}{*}{ After challenge } & Non-vaccinated & $90.79 \pm 38.75^{\mathrm{a}}$ & $22.19 \pm 2.82^{\mathrm{a}}$ & $1.16 \pm 0.07^{\mathrm{a}}$ & $18.13 \pm 10.77^{b}$ & $17.46 \pm 9.58^{b}$ \\
\hline & Saline & $58.48 \pm 44.25^{\mathrm{a}}$ & $22.25 \pm 3.26^{\mathrm{a}}$ & $1.12 \pm 0.08^{\mathrm{a}}$ & $27.39 \pm 5.21^{\mathrm{ab}}$ & $19.12 \pm 1.12^{\mathrm{b}}$ \\
\hline & $1 \times 10^{4}$ & $34.17 \pm 25.79^{b}$ & $22.33 \pm 2.04^{\mathrm{a}}$ & $1.17 \pm 0.28^{\mathrm{a}}$ & $30.44 \pm 8.84^{\mathrm{ab}}$ & $26.42 \pm 3.28^{b}$ \\
\hline & $1 \times 10^{8}$ & $21.05 \pm 17.24^{\mathrm{b}}$ & $21.86 \pm 1.91^{\mathrm{a}}$ & $1.19 \pm 0.12^{\mathrm{a}}$ & $42.46 \pm 4.21^{\mathrm{a}}$ & $37.66 \pm 4.21^{\mathrm{a}}$ \\
\hline
\end{tabular}

Table 3. Differential counting of leukocytes in the blood of Nile tilapia, before challenge ( 6 days after immunization) and $48 \mathrm{~h}$ after challenge with Aeromonas hydrophila. Non-vaccinated fish, fish injected with $1 \mathrm{~mL}$ saline solution, fish vaccinated with 1 x $10^{4}$ and $1 \times 10^{8} \mathrm{CFU}$ of polyvalent vaccine $/ \mathrm{mL}$. Different letters indicate significant difference among the treatments in each time of collection by SNK test of mean comparison $(\mathrm{P}<0.05)$.

El conteo diferencial de leucocitos en la sangre de tilapia del Nilo, antes del desafío (6 días después de la inmunización) y 48 h después del desafío con Aeromonas hydrophila. Peces no vacunados, peces inyectados con $1 \mathrm{~mL}$ de solución salina y peces vacunados con 1 x $10^{4}$ y 1 x $10^{8}$ UFC de vacuna polivalente/mL. Las letras distintas indican diferencia significativa entre los tratamientos en los distintos tiempos de colecta por el test de comparación de medias SNK $(\mathrm{P}<0.05)$.

\begin{tabular}{lllccc}
\hline Collection & \multicolumn{1}{c}{ Treatment } & $\begin{array}{c}\text { Basophill } \\
\left(10^{3} / \mu \mathrm{L}\right)\end{array}$ & $\begin{array}{c}\text { Neutrophill } \\
\left(10^{3} / \mu \mathrm{L}\right)\end{array}$ & $\begin{array}{c}\text { Lymphocyte } \\
\left(10^{3} / \mu \mathrm{L}\right)\end{array}$ & $\begin{array}{c}\text { Monocyte } \\
\left(10^{3} / \mu \mathrm{L}\right)\end{array}$ \\
\hline \multirow{3}{*}{ Before challenge } & Non-vaccinated & $0.58 \pm 0.55^{\mathrm{a}}$ & $7.83 \pm 3.72^{\mathrm{a}}$ & $9.51 \pm 4.46^{\mathrm{b}}$ & $0.27 \pm 0.23^{\mathrm{b}}$ \\
& Saline & $0.26 \pm 0.13^{\mathrm{a}}$ & $11.08 \pm 0.98^{\mathrm{a}}$ & $9.55 \pm 5.76^{\mathrm{b}}$ & $0.91 \pm 0.06^{\mathrm{a}}$ \\
& $1 \times 10^{4}$ & $0.33 \pm 0.13^{\mathrm{a}}$ & $9.50 \pm 1.40^{\mathrm{a}}$ & $14.21 \pm 3.17^{\mathrm{b}}$ & $1.66 \pm 0.88^{\mathrm{a}}$ \\
& $1 \times 10^{8}$ & $0.47 \pm 0.20^{\mathrm{a}}$ & $8.51 \pm 6.02^{\mathrm{a}}$ & $22.63 \pm 1.02^{\mathrm{a}}$ & $0.98 \pm 0.35^{\mathrm{a}}$ \\
\hline \multirow{3}{*}{ After challenge } & Non-vaccinated & $0.27 \pm 0.39^{\mathrm{a}}$ & $6.92 \pm 4.38^{\mathrm{a}}$ & $10.11 \pm 5.16^{\mathrm{b}}$ & $0.08 \pm 0.07^{\mathrm{a}}$ \\
& Saline & $0.05 \pm 0.08^{\mathrm{a}}$ & $10.62 \pm 1.88^{\mathrm{a}}$ & $8.44 \pm 2.93^{\mathrm{b}}$ & $0.00 \pm 0.00^{\mathrm{a}}$ \\
& $1 \times 10^{4}$ & $0.00 \pm 0.00^{\mathrm{a}}$ & $9.36 \pm 6.39^{\mathrm{a}}$ & $10.89 \pm 4.39^{\mathrm{b}}$ & $0.19 \pm 0.25^{\mathrm{a}}$ \\
& $1 \times 10^{8}$ & $0.17 \pm 0.16^{\mathrm{a}}$ & $9.99 \pm 8.78^{\mathrm{a}}$ & $20.28 \pm 2.70^{\mathrm{a}}$ & $1.08 \pm 1.07^{\mathrm{a}}$ \\
\hline
\end{tabular}


the other hand, reduced glucose concentration either before or after challenge corroborated the findings of Harikrishnan et al (2003).

Reduced number of erythrocytes and hemoglobin concentration was reported in cichlid (Etroplus suratensis) infected by ulcerative epizootic syndrome (Pathiratne and Rajapakshe 1998). Although no difference was observed in erythrocyte number of $A$. hydrophila infected fish, our results showed an increase after immunization when compared to unvaccinated fish.

According to Haney et al (1992), a decrease in the erythrocyte number and hemoglobin concentration may be caused by bacterial agent. A decrease in the number of erythrocyte and hematocrit percentage suggests that erythrocyte has been destructed by leukocytic activity. On the other hand, increased hematocrit is a result of oxygen depletion (Kirk 1974). In the present study, the infection and/or vaccine did not cause alteration in hematocrit percentage.

Similarly to the present results, an increase in the number of thrombocyte, lymphocyte and hematocrit percentage was also found in tilapia after challenge with Enterococcus sp. (Martins et al 2008 ${ }^{\mathrm{b}}$ ). In contrast to the observations in this assay, Martins et al $\left(2008^{\mathrm{b}}\right)$ did not relate influence of infection on glucose levels and erythrocyte number. They argued that this event occurred due to either insufficient inoculums to provoke these blood alterations or hematopoiesis. Contrarily to our results, Lamas et al (1994) and Balfry et al (1997) found a reduced number of lymphocytes in the blood of rainbow trout and tilapia, infected with $V$. anguillarum and $V$. parahaemolyticus, respectively. Our results with $1 \times 10^{8}$ bacteria-injected fish can be explained by the fact that lymphocytes have migrated to injured site, as found by Martins et al $\left(2009^{\mathrm{b}}\right)$.

After immunization the number of monocytes was significantly lower $(\mathrm{P}<0.05)$ in non-vaccinated fish (table 3$)$. Monocytes have phagocytic activity and differentiate in macrophages in order to migrate to an inflammatory site like a defense response (Griffin 1984, Martins et al $2009^{\mathrm{a}}$ ). This is especially true by the fact that vaccinated and saline-injected fish showed an increase in these cells confirming their action on the fish defense system.

Glucose concentration can increase in short periods in order to supply the energetic demand in stress situations as commented by Barton (2000). In this assay glucose levels did not alter before and after challenge in non-vaccinated and saline-injected fish. In $1 \times 10^{4}$ and $1 \times 10^{8}$ vaccinated fish glucose decreased after challenge (table 2). On the other hand, in infected carp treated with herbal extract an increase in the glucose concentration was observed 30 days after infection (Harikrishnan et al 2003). Our results confirmed the comments of Barton (2000). In fact, after both immunization and challenge, the fish was trying to supply the energetic demand in this situation of bacterial stress.

\section{AGGLUTINATION TITER}

After immunization and challenge fish vaccinated with $1 \times 10^{8} \mathrm{CFU}$ inactivated bacteria/mL stimulated the agglutination titer against $A$. hydrophila, $P$. aeruginosa and E. durans (table 4). An increase in the agglutination titer in fish after immunization was reported by other authors. In the Studies on Seriola quinqueradiata vaccination

Table 4. Agglutination titer $\left(\log _{2}(\mathrm{x}+1)\right)$ in the serum of Nile tilapia, before challenge (6 days after immunization) and $48 \mathrm{~h}$ after challenge with Aeromonas hydrophila. Non-vaccinated fish, fish injected with $1 \mathrm{~mL}$ saline solution, fish vaccinated with $1 \mathrm{x} 10^{4}$ and $1 \times 10^{8} \mathrm{CFU}$ of polyvalent vaccine/mL. Different letters indicate significant difference among the treatments in each time of collection by SNK test of mean comparison $(\mathrm{P}<0.05)$.

Título de aglutinación $\left(\log _{2}(\mathrm{x}+1)\right.$ ) en el suero de tilapia del Nilo, antes del desafío (6 días después de la inmunización) y 48 h después del desafío con Aeromonas hydrophila. Peces no vacunados, peces inyectados con $1 \mathrm{~mL}$ de solución salina y peces vacunados con 1 x $10^{4}$ y 1 x $10^{8}$ UFC de vacuna polivalente/mL. Las letras distintas indican diferencia significativa entre los tratamientos en los distintos tiempos de colecta por el test de comparación de medias SNK $(\mathrm{P}<0.05)$.

\begin{tabular}{|c|c|c|c|c|}
\hline \multirow{2}{*}{ Collection } & \multirow{2}{*}{ Treatment } & \multicolumn{3}{|c|}{ Agglutination titer } \\
\hline & & Aeromonas hydrophila & Pseudomonas aeruginosa & Enterococcus durans \\
\hline \multirow{4}{*}{$\begin{array}{l}\text { Before } \\
\text { challenge }\end{array}$} & Non-vaccinated & $2.64 \pm 0.92^{b}$ & $0.00 \pm 0.0^{b}$ & $3.51 \pm 1.39^{\mathrm{b}}$ \\
\hline & Salina & $2.89 \pm 0.49^{b}$ & $0.00 \pm 0.0^{b}$ & $3.57 \pm 1.79^{b}$ \\
\hline & $1 \times 10^{4}$ & $3.17 \pm 0.55^{\mathrm{b}}$ & $0.00 \pm 0.0^{\mathrm{b}}$ & $5.05 \pm 0.97^{b}$ \\
\hline & $1 \times 10^{8}$ & $8.34 \pm 0.58^{\mathrm{a}}$ & $5.38 \pm 1.12^{\mathrm{a}}$ & $7.01 \pm 0.99^{\mathrm{a}}$ \\
\hline \multirow{4}{*}{$\begin{array}{l}\text { After } \\
\text { challenge }\end{array}$} & Non-vaccinated & $2.08 \pm 0.43^{\mathrm{c}}$ & $0.53 \pm 0.92^{b}$ & $4.73 \pm 0.55^{\mathrm{b}}$ \\
\hline & Salina & $3.23 \pm 1.57^{\mathrm{bc}}$ & $0.77 \pm 1.34^{\mathrm{b}}$ & $4.09 \pm 0.00^{\mathrm{b}}$ \\
\hline & $1 \times 10^{4}$ & $4.73 \pm 0.55^{\mathrm{b}}$ & $1.83 \pm 0.43^{b}$ & $4.41 \pm 0.55^{\mathrm{b}}$ \\
\hline & $1 \times 10^{8}$ & $11.33 \pm 0.58^{\mathrm{a}}$ & $6.04 \pm 0.57^{\mathrm{a}}$ & $6.68 \pm 0.57^{\mathrm{a}}$ \\
\hline
\end{tabular}


against Photobacterium damsela piscicida, Gravningen et al (2008) detected increased antibody levels three and four weeks after immunization.

Similar to our results, higher antibody levels for two weeks were reported in tilapia vaccinated intraperitoneally with A. hydrophila (Ruangpan et al 1986). On the other hand, Swain et al (2007) have related the efficacy of poli or monovalent vaccine in cyprinid fish (Labeo rohita) with the maximum values of agglutination titer after 4 weeks. In this assay, the highest agglutination titer was found after injection with $1 \times 10^{8} \mathrm{CFU}$ bacteria/mL.

In conclusion, polyvalent vaccine at a concentration $1 \times 10^{8} \mathrm{CFU} / \mathrm{mL}$ stimulated the erythrocyte production, total leukocyte counting, monocyte and lymphocyte number, important cells involved on the specific and nonspecific immunological process.

Fish vaccinated with the highest dose also stimulated the thrombocyte and leukocyte production after challenge. An increase in the agglutination titer against $A$. hydrophila, $P$. aeruginosa and $E$. durans was found either after immunization or challenge with A. hydrophila. However, further studies must be developed to solve the defense mechanisms in the Brazilian cultured fish to enhance the vaccine efficacy. Moreover, studies should be carried out to evaluate the cumulative mortality in fish treated with different vaccine doses regarding to field application and the duration of vaccine efficacy.

\section{SUMMARY}

This study evaluated the effects of polyvalent vaccination on the hematological and serum agglutination responses in Nile tilapia challenged with Aeromonas hydrophila. Two dosis, $1 \times 10^{4}$ and $1 \times 10^{8}$ ) Colony Forming Units (CFU)/mL, of vaccine containing the same amount of Aeromonas hydrophila, Pseudomonas aeruginosa and Enterococcus durans formalin-inactivated were tested by intraperitoneal (i.p) injection. Fish were challenged ten days after vaccination i.p. with a $\mathrm{DL}_{50-96 \mathrm{~h}}$ of $1 \times 10^{7} \mathrm{CFU} A$. hydrophila $/ \mathrm{mL}$. Samples were collected $48 \mathrm{~h}$ after challenging fish to check the hematological parameters, antimicrobial activity and agglutination titer of serum, samples were collected $48 \mathrm{~h}$ after challenge. Before challenge, the number of erythrocytes was higher in fish vaccinated with $1 \times 10^{8}$ $\mathrm{CFU} / \mathrm{mL}$. After challenge, total number of thrombocytes was higher in fish that received the greatest dose of vaccine. Before and after challenge, total number of leukocytes and the number of lymphocytes showed the highest values in vaccinated fish. Before challenge, increased number of monocytes in vaccinated and saline-injected fish was observed. The highest agglutination titer against $A$. hydrophila, $P$. aeruginos $a$ and $E$. durans was related in $1 \times 10^{8} \mathrm{CFU} / \mathrm{mL}$ vaccinated fish. Before challenge, high values of antimicrobial activity in non-vaccinated fish and $1 \times 10^{8} \mathrm{CFU} / \mathrm{mL}$ vaccinated ones was also related. Therefore, after challenge, non-vaccinated fish and saline-injected ones showed the highest antimicrobial activity. This study showed that 10 days after immunization with a polyvalent vaccine at a concentration $1 \times 10^{8} \mathrm{CFU} / \mathrm{mL}$, there was an increase on erythrocytes, leukocytes, thrombocytes and circulating lymphocytes production, while the glucose levels were reduced.

\section{ACKNOWLEDGEMENTS}

The authors thank CNPq (Conselho Nacional de Desenvolvimento Científico e Tecnológico) for financial support (CNPq 472968/2007-6) and grant to M.L. Martins (CNPq 301072/2007-8).

\section{REFERENCES}

Abdel-Tawwab M, AM Abdel-Rahman, NEM Ismael. 2008. Evaluation of commercial live bakers yeast, Saccharomyces cerevisiae as a growth and immunity promoter for Fry Nile tilapia, Oreochromis niloticus (L.) challenged in situ with Aeromonas hydrophila. Aquaculture 280, 185-189.

Balfry SK, M Shariff, GK Iwama. 1997. Strain differences in non-specific immunity of tilapia Oreochromis niloticus following challenge with Vibrio parahaemolyticus. Dis Aquat Org 30, 77-80.

Barton BA. 2000. Salmonid fishes differ in their cortisol and glucose responses to handling and transport stress. North Am J Aquac 62, 12-18.

Bly JE, SMA Quiniou, LW Clem. 1997. Environmental effects in fish immune mechanisms. Dev Biol Stand 90, 33-43.

Castro N, AE Toranzo, S Nuñes, B Magariños. 2008. Development of an effective Edwardsiella tarda vaccine for cultured turbot (Scophthalmus maximus). Fish and Shellfish Immunol 25, 208-212.

Costa AB. 2004. Estratégias para o estudo de bactérias potencialmente patogênicas na piscicultura. In: Cyrino JEP, Urbinati EC, Fracalossi DM, Castagnolli N (eds). Tópicos especiais em piscicultura de água doce tropical intensiva, 1. ed. São Paulo: TecArt, cap. 13, Pp 387-404.

Garcia F, F Pilarski, EM Onaka, FR Moraes, ML Martins. 2007. Hematology of Piaractus mesopotamicus fed diets supplemented with vitamins $\mathrm{C}$ and $\mathrm{E}$, challenged by Aeromonas hydrophila. Aquaculture 271, 39-46.

Goldenfarb PB, FP Bowyer, E Hall, E Brosious. 1971. Reproductibility in the hematology laboratory: the microhematocrit determination. Am J Clin Pathol 56, 35-39.

Gravningen K, M Sakai, C Mishiba, T Fujimoto. 2008. The efficacy and safety of an oil-based vaccine against Photobacterium damsela subsp. piscicida in yellowtail (Seriola quinqueradiata): A field study. Fish and Shellfish Immunol 24, 523-529.

Griffin RB. 1984. Random and directed migration of trout (Salmo gairdneri) leukocytes: activation by antibody, complement, and normal serum components. Dev Comp Immunol 8, 589-597.

Gudding R, A Lillehaug, O Evensen. 1999. Recent developments in fish vaccinology. Vet Immunol Immunopathol 72, 203-212.

Gudmundsdottir BK, B Björnsdóttir. 2007. Review - Vaccination against atypical furunculosis and winter ulcer disease of fish. Vaccine 25, 5512-5523.

Hamilton MA, RC Russo, V Thurston. 1977. Trimmed Spearman-Karber method for estimating medial lethal concentrations in toxicology bioassays. Environm Sci Tech 7, 714-719.

Haney DC, DA Hursh, MC Mix, JR Winton. 1992. Physiological and hematological changes in chum salmon artificially infected with erythrocytic necrosis virus. J Aquat Anim Health 4, 48-57.

Harikrishnan R, MN Rani, C Balasundaram. 2003. Hematological and biochemical parameters in common carp, Cyprinus carpio, following herbal treatment for Aeromonas hydrophila infection. Aquaculture 221, 41-50.

Ishikawa NM, MJT Ranzani-Paiva, JV Lombardi. 2008. Metodologia para quantificação de leucócitos totais em peixe, Oreochromis niloticus. Arch Vet Sci 13, 54-63.

Jatobá A, FN Vieira, CC Buglione Neto, BC Silva, JLP Mouriño, GT Jerônimo, G Dotta, ML Martins. 2008. Utilização de bactérias ácido-lácticas isoladas do trato intestinal de tilapia do Nilo como probiótico. Pesq Agropec Bras 43, 1201-1207.

Kirk WL. 1974. The effects of hypoxia on certain blood and tissue electrolytes of channel catfish, Ictalurus punctatus (Rafinesque). Trans Am Fish Soc 103, 593-600.

Klesius PH, CA Shoemaker, JJ Evans. 2000. Efficacy of single and combined Streptococcus iniae isolate vaccine administered by intraperitoneal and intramuscular routes in tilapia (Oreochromis niloticus). Aquaculture 188, 237-246. 
Lamas J, Y Santos, DW Bruno, AE Toranzo, R Anadon. 1994. Non-specific cellular responses of rainbow trout to Vibrio anguillarum and its extracellular products (ECPs). J Fish Biol 45, 839-854.

Lillehaug A, A Ramstad, K Baekken, LJ Reitan. 1993. Protective immunity in Atlantic salmon (Salmo salar L.) vaccinated at different water temperatures. Fish and Shellfish Immunol 3, 143-56.

Martins ML, FR Moraes, RY Fujimoto, EM Onaka, FR Bozzo, JRE Moraes. 2006. Carrageenin induced inflammation in Piaractus mesopotamicus (Osteichthyes: Characidae) cultured in Brazil. Bol Inst Pesca 32, 31-39.

Martins ML, DMY Miyazaki, FR Moraes, L Ghiraldelli, WB Adamante, JLP Mouriño. 2008'. Vitamin C and E supplemented diet influences the acute inflammatory response in Nile tilapia. Ciencia Rural 38, 213-218.

Martins ML, JLP Mouriño, GV Amaral, FN Vieira, G Dotta, AJM Bezerra, FS Pedrotti, GT Jerônimo, CC Buglione-Neto, G Pereira Jr. 2008 ${ }^{\mathrm{b}}$. Haematological changes in Nile tilapia experimentally infected with Enterococcus sp. Braz J Biol 68, 631-637.

Martins ML, FN Vieira, GT Jerônimo, JLP Mouriño, G Dotta, GM Speck, AMB Jatobá, FS Pedrotti, CC Buglione-Neto, G Pereira Jr. 2009 ${ }^{\text {a }}$ Leukocyte response and phagocytic activity in Nile tilapia experimentally infected with Enterococcus sp. Fish Physiol Biochem 35, 219-222.

Martins ML, DMY Myiazaki, M Tavares-Dias, J Fenerick Jr, EM Onaka, FR Bozzo, RY Fujimoto, FR Moraes. 2009 ${ }^{\mathrm{b}}$. Characterization of the acute inflammatory response in the hybrid tambacu (Piaractus mesopotamicus malex Colossoma macropomum female) (Osteichthyes). Braz J Biol 69, 631-637.

Nakanishi T, M Ototake. 1997. Antigen uptake and immune responses after immersion vaccination. 1997. In: Gudding R, Lillehaug A, Midtlyng PJ, Brown F (eds). Dev Biol Stand, 90, 59-68.

Park KH, HD Jeong. 1996. Enhanced resistance against Edwardsiella tarda infection in tilapia (Oreochromis niloticus) by administration of protein-boun polysaccharide. Aquaculture 143, 135-143.

Pathiratne A, W Rajapakshe. 1998. Hematological changes associated with epizootic ulcerative syndrome in the Asian cichlid fish Etroplus suratensis. Asian Fish Sci 11, 203-211.

Pickering AD. 1981. Stress and Fish. Academic Press, New York, USA, Pp 1-10.

Rahman MH, K Kawai, R Kusuda. 1997. Virulence of starved Aeromonas hydrophila to cyprinid fish. Fish Pathology 32, 163-168.

Rosenfeld G. 1947. Corante pancrômico para hematologia e citologia clínica. Nova combinação dos componentes do May-Grünwald e do Giemsa num só corante de emprego rápido. Mem Inst Butantan 20, 329-334.

Ruangpan L, T Kitao, T Yoshida. 1986. Protective efficacy of Aeromonas hydrophila: vaccines in Nile tilapia. Vet Immunol Immunopathol 12, 345-350.

Sarder MRI, KD Thompson, DJ Penman, BJ McAndrew. 2001. Immune responses of Nile tilapia (Oreochromis niloticus L.) clones: I. Nonspecific responses. Dev Comp Immunol 25, 37-46.

Schreck CB. 1996. Immunomodulation: endogenous factors. In: Iwana G, Nakanishi T (eds). The fish immune system, organism, pathogen and environment. Academic Press, London, UK, Pp 311-337.

Swain P, A Behura, S Dash, SK Naya. 2007. Serum antibody response of Indian major carp, Labeo rohita to three species of pathogenic bacteria, Aeromonas hydrophila, Edwardsiella tarda and Pseudomonas fluorescens. Vet Immunol Immunopathol 117, 137-141.

Tatner MF, MJ Manning. 1983. The ontogeny of cellular immunity in the rainbow trout, Salmo gairdneri Richardson, in relation to the stage of development of the lymphoid organs. Dev Comp Immunol 7, 69-75.

Tatner MF. 1987. The quantitative relationship between vaccine dilution, length of immersion time and antigen uptake, using a radiolabelled Aeromonas salmonicida bath in direct immersion experiments with rainbow trout, Salmo gairdneri. Aquaculture $62,173-185$.

Van Muiswinkel WB, DP Anderson, CHJ Lamers, E Egberts, JJA Van Loon, JP Ijssel. 1985. Fish immunology and fish health. In: Manning MJ, Tatner MF (eds). Fish Immunology. Academic Press, London, UK, Pp 1-8.

Walters GR, JA Plumb. 1980. Enviromental stress and bacterial infection in channel catfish, Ictalurus punctatus Rafinesque. J Fish Biol $17,177-185$.

Wang WS, DH Wang. 1997. Enhancement of the resistance of tilapia and grass carp to experimental Aeromonas hydrophila and Edwardsiella tarda infections by several polysaccharides. Comp lmmunol Microbiol Infec Dis 20, 261-270.

Wassom DL, EAB Kelly. 1990. The role of the major histo-compatibility complex in resistance to parasite infections. Crit Review Immunol $10,31-52$.

Yildirim M, C Lim, P Wan, PH Klesius. 2003. Growth performance and immune response of channel catfish (Ictalurus punctatus) fed diets containing graded levels of gossypol-acetic acid. Aquaculture 219, 751-768. 